\title{
炭素繊維単繊維試料の引張り荷重-伸び挙動
}

\author{
温品 恭彦*, 松井 醇一**, 伊藤 基** \\ (1989 年 1 月 10 日受付)
}

\section{On the Tensile Load to Elongation Response of Carbon Fibre Single Filament Samples}

\author{
Y. Nukushina,* J. MAtSui** and M. ITOH** \\ (Received January 10, 1989)
}

\begin{abstract}
Tensile modulus of elasticity for unidirectional carbon fibre composites increases proportionally with increasing stress (or strain). This phenomenon has been known as a stress stiffening effect. In the present paper tensile load to elongation response for carbon fibre single filament samples was studied precisely by a mechanical measurement technique. It was found that the stress induced stiffening effect is intrinsic characteristics of the carbon fibre.
\end{abstract}

\section{1. 緒}

論

炭素繊維および炭素繊維を一方向に配列した樹脂複合 材料に引張り応力を加えたとき，引張り弾性率が応力の 増大（あるいは伸びの増大といっても同じであるが）と ともに大きくなることが知られている，炭素織維マルチ フィラメント糸の構成単位の単纎維について Curtis ら および Beetz ら,マルチフィラメント釆にエポキシ樹 脂を含浸したあと加熱して硬化させた細い棒状の複合材 料（樹脂含浸ヤーンとよぶことにする）について温品ら 扣よび Hughes, 一方向配列複合材料について van Dreumel らおよび石川らによって報告されている1-6). また日本工業規格 JIS R7601-1986 炭素繊維試験方法お よびドイッ工業規格 DIN/LN 29965 Kohlenstoffasern, Kohlenstoffgarne, Technische Lieferbedingungen で は，樹脂含浸ヤーン試料を用いた引張り試験における引 張り弾性率の計算を行ならにあたり，この特性を考虑し て伸びまたは応力の範囲を規定している.

樹脂含浸ヤーンおよびプリブレグを積層して成型した 一方向配列複合材料は, 単瀻維の屈曲, 偏角, 旋回によ る配列の乱れは避けることができず，このような乱れの

* 滋賀女子短期大学教授 (520 大津市竜ヶ丘 24-2) Professor, Shiga Women's Junior College, 242, Tatsugaoka, Otsu 520, Japan

** 東レ $\mathrm{ACM}$ 技術部（103 中央区日本橋室町 22-1)

Toray Ind., Inc. ACM Technology Dept., 2-2-1, Nihonbashi-Muromachi, Chuo-ku, Tokyo 103, Japan
程度が応力によって変化するために弾性率が大きくなる と考えることもできる．この点を解明するため本研究で は単繊維試料について, 力学的手段によって精密に荷重 と伸びの関係を調夜し，配列の乱れの要素を排除した場 合の炭素繊維の弾性率の応力依存性を明らかにした。

単繊維を試験片に用いて引張り試験を行なら場合に は，伸び部を試験片に取り付けることができないため， 伸びはクロスヘッド移動量をシステムコンプライアンス で補正して求めるのが普通である7. しかし本研究の目 的とする弾性率の伸び依存性の調査のためには, 精度の 点で適用できない．Curtis らは $0.75 \mathrm{MHz}$ の音波伀播 から弾性率を求め, 試験片に加えられた応力と弾性率の 関係を報告している．この実験では弾性率の異なる 2 種 類の PAN 系炭素繊維 Type I $\left(2,600^{\circ} \mathrm{C}\right.$ 熱処理品) お よび Type II $\left(1,500^{\circ} \mathrm{C}\right.$ 熱処理品) を用い, 引張り荷重を $0.1 \mathrm{gf}$ から $6 \mathrm{gf}$ まで変化させて弾性率を測定した。両 方の試料について $0.1 \mathrm{gf}$ から $2.5 \mathrm{gf}$ までは急激に弾性 率が高くなり，2.5 gf から $6 \mathrm{gf}$ の間では荷重に比例し て単調増加することを認めている，荷重の大きさによっ て 2 段階の変化を示すことに対して, $2.5 \mathrm{gf}$ 以下の初期 部分は結晶の転位, $2.5 \mathrm{gf}$ 以上の比例部分に配向の変化 によると推察している1。. また Ruland らはX線回折に よって沁力份街による微細構造の変化を調查し, 弾性率 が高くなる理由を推察している8). Beetz らは, PAN 系 “Thornel” 300 扩よびメソフェーズピッチ系 “Thornel”-P55, -P100を試料に用い, 動的歪変調法 (Dynamic strain modulation technique) によって振動数 $1 \mathrm{~Hz}$ か 
Table 1 Details of carbon fibre samples.

\begin{tabular}{|c|c|c|c|c|c|c|}
\hline Manufacturer & Brand name & Type & $\begin{array}{l}\text { Filament } \\
\text { number }\end{array}$ & $\begin{array}{l}\text { Tensile } \\
\text { strength } \\
\text { at } \\
\text { failure } \\
\left(\mathrm{kgf} / \mathrm{mm}^{2}\right)\end{array}$ & $\begin{array}{l}\text { Tensile } \\
\text { modulus } \\
\text { of } \\
\text { elasticity } \\
\left(\mathrm{kgf} / \mathrm{mm}^{2}\right)\end{array}$ & $\begin{array}{l}\text { Ultimate } \\
\text { percentage } \\
\text { elongation } \\
\text { at failure } \\
\quad(\%)\end{array}$ \\
\hline Toray & “Torayca” & T 300 & 3000 & 388 & 24000 & 1.6 \\
\hline \multirow[t]{3}{*}{ Industries } & & $\mathrm{T} 400$ & 6000 & 453 & 25500 & 1.8 \\
\hline & & $\mathrm{T} 800$ & 12000 & 572 & 29700 & 1.9 \\
\hline & & M46 & 6000 & 242 & 46000 & 0.5 \\
\hline \multirow[t]{2}{*}{ Hercules } & "Magnamite" & AS4 & 6000 & 442 & 25500 & 1.7 \\
\hline & & IM6 & 12000 & 559 & 29000 & 1.9 \\
\hline
\end{tabular}

Tensile properties were measured with resin impregnated yarn specimens according to JIS R7601-1986.

"Bakelite" ERL4221-BF 3 - MEA resin system was used for impregnating the yarn.

ら $15 \mathrm{~Hz}$ の間で弾性率を測定した. Beetz らの得た絬 果は， 3 種類の試料のすべてについて $0.5 \mathrm{gf}$ までのご く初期に急激な立上りがあるが，0.5 gf 以上では荷重と 弾性率の間に比例関係が成立する。Curtis らの場合之举 動は似ているが，荷重と弾性率の関係の変曲点が低荷重 側に存在すること拉よ゙初期の立上りは結晶の転位では 説明がつかないことを述べている22.

本研究では, 伸びを光学式非接触型長さ計を用い, 孷 素繊維の荷重と伸びの関係を機械的な力法によって測定 し, 弾性率に対する伸び（招よび応力）の影響を明らか にした。また樹脂含浸ヤーン試料との比較を行ない, 配 列の乱れの効果について考察した.

\section{2. 実験}

\section{1 試料}

本研究はPAN 系炭素繊維 6 種類を用いて行なった。 試料の明細を Table 1 に示す。表の値はマルチフィラメ ント糸 (単繊維が 3,000 本, 6,000 本特よび 12,000 本 集合した織維束）を用い，繊維含浸ヤーン法によって測 定した。試験力法は JIS R7601-1988 に従った。

単繊維試験片のサンブリングのためにはサイジング剤 の付着していない試料が必要である。サイジング剂の除 去は，試料を濃硫酸中に室温下で 50 時間浸漬したのち 水洗して行なった。

\section{2 試 験装 置}

荷重一伸び関係の測定は, 前報と同様に光学式非接触型 長さ計とテンシロン引張り試験機を組み合わせた装置を 用いた92。前報と異なる点をあげると、ロードセルは東 洋ボールドウィン社製 TLU-0.10 LF (容量 100 gf)，チ

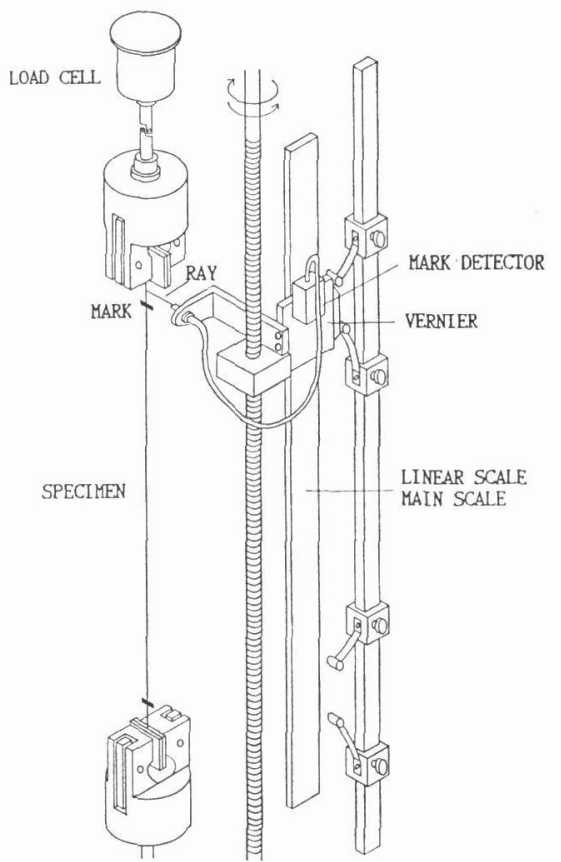

Fig. 1 Schematic drawing of principal parts of the tensile tester.

ヤックは小型のバネ作動式の Instron 社製 Fibercramp 2711-010を用いた（Fig.1).

\section{3 試 験 方 法}

\section{3.1 引張り試験}

引張り試験は, 次のように行なった。

(1) 絨維束から無作為に採取した長さ $1,000 \mathrm{~mm}$ の 単繊維 1 本を試験片とし, 引張り試験機の上下のクラン 
プでつかを.

（2）試験片に幅 $5 \mathrm{~mm}$ ，拉さ $10 \mathrm{~mm} の$ 粘着紙を貼り， 長さ読取りの標点と寸る. 標点の粘着紙は, 試験片の上: 下 2 力所に所定の試長の距離を離して貼る。

（3）减り試験機を駆動し，試験片を年分 $4 \mathrm{~mm}$ の速 度で引張る。荷重が 0.3 gf に達すると駆動を停怩:し， この状態で標点間長さを測定する.

（4）荷重を $0.3 \mathrm{gf}$ きざに段階的に試料の破壊荷重! の約 $80 \%$ まで増加し, 各荷重下の梆点間長さを測定す る.このようにして負荷側の荷重一伸び関係を求める.

（5）次に荷重を $0.3 \mathrm{gf}$ きさみに段階的に減少し，各 荷重下の標点間長さを測定し, 除荷側の荷重-伸び関係を 求める.

ただし“トレカ”M46 は破断伸びが $0.5 \%$ と小さい ため，荷重 $0.3 \mathrm{gf}$ きざみでは测定点数が少ない，この 試料に限り荷重間隔を 0.2 gf とした。

試長は，とくに規定しない場合 $900 \mathrm{~mm}$ とした。荷 重一伸び関係の試長依存性を調べるため, 試長 $330 \mathrm{~mm}$, $450 \mathrm{~mm}$ および $650 \mathrm{~mm}$ の実験を行なった。

荷重一伸び関係は, 負荷側と除荷側の 1 往復について測 定したが，繰返しの効果をみるため同一試料を倣いて 4 往復の負荷と除荷の丰験を行なった。

\section{3 .2 単織維の断面積の測定}

単繊維の断面の測定は, JIS にしたがい次のように行 なった.

（1）試料の繊維束の単位長さ当り質量, 密度および繊 維束を構成する単纎維の本数から, 次式によって計算で 求める.

$$
A=\frac{t}{d} \cdot \frac{1}{f} \cdot 10^{9}
$$

ここに,

$A$ は単㵶維の平均断面積 $\left(\mu \mathrm{m}^{2}\right)$

$t$ は試料繊維束の単位長さ当り質量 $(\mathrm{g} / 1,000 \mathrm{~mm})$

$d$ は試料繊維束の密度 $\left(\mathrm{g} / \mathrm{cm}^{3}\right)$

$f$ は試料繊維束を構成する単繊維の本数の公称値

この方法は， $f$ が既知であり，単纎維の断面積のばら つきが小さい場合に適用できる.

（2）単位長さ当り質量は，陚料がまっすぐになる程度 の荷重（約 100 gf）を吊した状態で，百定規を用いて $1,000 \pm 1 \mathrm{~mm}$ の試験片を片刃ナイフで切り取り，0.1 $\mathrm{mg}$ の桁まで科量して測定した。同一試料から 3 個の試 験片について测定し，その平均値を $\boldsymbol{t}$ とした。

（3）密度は，単位長さ当り質量を測定した試験片を用 い, $23 \pm 3^{\circ} \mathrm{C}$ における 0 -ジクロロベンゼン中の質量を測
运し，空爻中の質剈と液中の質量の差および液の密度か ら算出した。 3 侗の测定值の平均值をdとした。

\subsection{3 単緎維の断面積のばらつきの測定}

単繊維の断面積のばらつきを調べる目的で，次の方法 によって断面積を測定した。しかし，この測定は二，三 の試料についてのみ行なった。

(1) 断面の走植電子顕微鏡写真をイメージアナライザ ーによって処理する才j法

単繊維 50 本ないし 100 本をエポキシ樹脂（リファ インテックス社試料埋込用）に包埋し，顕微鏡観察試料 作製用白動研磨器を用いて研磨する。 その表面に炭素を 蒸着したのち電界放射走査電子顕微鏡（日立製作所製 S800 型)によって, 加速電圧 $25 \mathrm{kV}$ で単繊維断面の写 真を撮影する．写真は 2,000 倍にブリントし，この写 真をイメージアナライザ (Cambridge Instrument 社製 Quantiment 900) によって処理し，個々の単繊維の断 面積を求める.

（2） 向励振動を起こす振動数と密度から算出する方法 一端に質量 $W$ の荷重を吊した長さ $L$ の繊維試験片に 自励発振系を形成することによって，固有振動数 $F$ を求 めることができる．試験片の単位長さ当りの質量 $t$ は, $L, W$ おび $F$ から次式によって算出する.

$$
t=\frac{W}{L^{2} \cdot F^{2}}
$$

この方法は, 天然繊維および合成繊維の $t$ を求めるため に広く用いられており，炭素繊維への応用例もある9 $t$ と密度 $d$ が与兄られると，試験片の断面積は $t / d$ と して求めることができる。本研究では“トレカ” T300 について, Denicom DC-2B 型（旭光精工社製）によっ て $L=25 \mathrm{~mm}, W=50 \mathrm{mg}$ で $F$ を測定し,$d$ は㵶維束に ついて得られた $1.78 \mathrm{~g} / \mathrm{cm}^{3}$ を用いて断面積を算出した (単繊維試験片の密度ではなく, サンプリングの母体の 繊維束の密度を使用した)。

\subsection{4 引張り弾性率の計算}

引張り弾性率は，荷重一伸び関係において，ある荷重 $P_{i}$ (たとえば $1.5 \mathrm{gf}$ ) に対し $0.45 \mathrm{gf}$ 大きい荷重 $P_{i+0.45}$ (1.95 gf) 扰よび 0.45 gf 小さい荷重 $P_{i-0.45}$ (1.05 gf) における伸び $\varepsilon_{i+0.45}$ (Table 2 の場合 $0.196 \%$ ) および $\varepsilon_{i-0.45}(0.084 \%)$ を求め, 次式によって計算し, 荷重 $P_{i}$ および伸び $\varepsilon_{i}$ における弾性率 $E_{i}$ とした。

$$
E_{i}=\frac{\Delta P_{i}}{\Delta \varepsilon_{i}} \cdot \frac{1}{A}
$$

ここに,

$E_{i}$ は荷重 $P_{i}$ および伸び $\varepsilon_{i}$ における引張り弾性率 

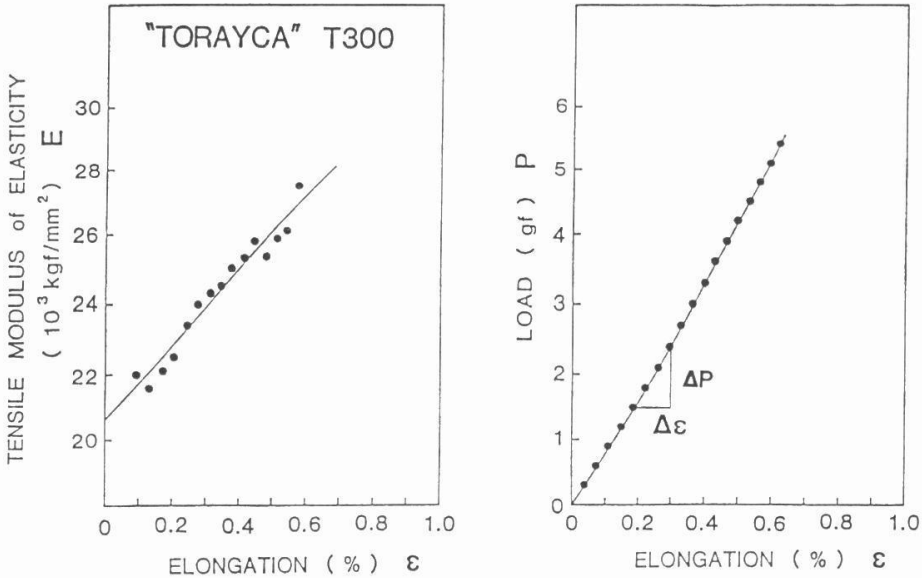

Fig. 2 Normal load vs. elongation, and tensile modulus vs. elongation for "Torayca" T300 fibre.
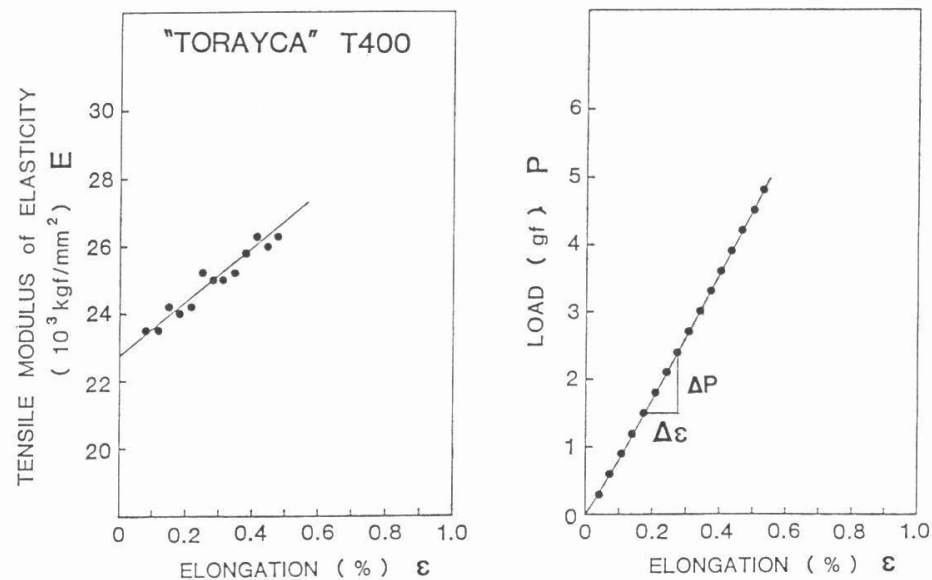

Fig. 3 Normal load vs. elongation, and tensile modulus vs. elongation for "Torayca" T400 fibre.

$\left(\mathrm{kgf} / \mathrm{mm}^{2}\right)$

$\Delta P_{i}$ は荷重 $P_{i-0.45}$ と $P_{i+0.45}$ の差 $0.9 \mathrm{gf}$ の一定値. ただじトレカ”M46の場合は $\Delta P_{i}$ は $0.6 \mathrm{gf}$ $\Delta \varepsilon_{i}$ 畒重 $P_{i-0.45}$ における伸び $\varepsilon_{i-0.45}$ と $P_{i+0.45}$ における $\varepsilon_{i+0.45}$ の差 $(\%)$ $A$ は式 (1)から求めた単瀻維の平均断面積 $\left(\mu \mathrm{m}^{2}\right)$

\section{3. 結果と考察}

“トレカ” T300 について負荷時および除荷時の荷重一 伸び関係を測定した結果，次のことが涩められた。

（1）負荷時と除荷時の荷重一伸び関係は同一である. 小数点以下 2 桁でわずかに差が認められる。この結
果は 4 往復の负荷上除荷についてもあてはまる。ま た試辰に注目すると，负荷前といったん負荷してか ら除條した後の試長は同一であるし，4往復の負荷 と除荷の繰返しによっても無負荷（正しくは0.2 gf 負荷) 時の試長は変化しない，実験結果を Table 2 に示す。この結果から, 炭素繊維は弾性体であるこ とがわかる。

（2）荷重一伸び関係は非線性を示し,荷重が大きくなる とともに（すなわら伸びが大きくなるとともに）一 企荷重を加党た場合の伸びの変化が小さくなる。こ の状況を Fig. 2 から Fig.7 の右例に示吉. 測定し たすべての試料についてこの現象が熟められる。次 
Table 2 Load-elongation and tensile

\begin{tabular}{|c|c|c|c|c|c|c|c|c|c|c|}
\hline \multirow{2}{*}{$\begin{array}{l}\text { Load } \\
\text { (gf) }\end{array}$} & \multicolumn{4}{|c|}{1 st } & \multicolumn{4}{|c|}{2 nd } & \multicolumn{2}{|c|}{$3 \mathrm{rd}$} \\
\hline & $\begin{array}{c}\text { Elon- } \\
\text { gation } \\
\varepsilon \\
(\%)\end{array}$ & $\begin{array}{c}\Delta \varepsilon \\
(\%)\end{array}$ & $\begin{array}{c}\text { Elon- } \\
\text { gation } \\
\varepsilon \\
(\%)\end{array}$ & $\begin{array}{c}\Delta \varepsilon \\
(\%)\end{array}$ & $\begin{array}{c}\text { Elon- } \\
\text { gation } \\
\varepsilon \\
(\%)\end{array}$ & $\begin{array}{c}\Delta \varepsilon \\
(\%)\end{array}$ & $\begin{array}{c}\text { Elon- } \\
\text { gation } \\
\varepsilon \\
(\%)\end{array}$ & $\begin{array}{c}\Delta \varepsilon \\
(\%)\end{array}$ & $\begin{array}{c}\text { Elon- } \\
\text { gation } \\
\varepsilon \\
(\%)\end{array}$ & $\begin{array}{c}\Delta \varepsilon \\
(\%)\end{array}$ \\
\hline 0.3 & 0.004 & $-\quad \ldots 30$ & 0.003 & (307) & 0.003 & .... & 0.003 & & 0.001 & \\
\hline 0.6 & 0.034 & . & 0.030 & & 0.027 & 0.024 & 0.023 & 0.020 & 0.029 & 0.020 \\
\hline 0.9 & 0.069 & 0.035 & 0.063 & 0.033 & 0.062 & 0.035 & 0.058 & 0.035 & 0.065 & 0.036 \\
\hline 1.2 & 0.108 & $\begin{array}{r}0.039 \\
\end{array}$ & 0.103 & 0.040 & 0.100 & 0.038 & 0.096 & & 0.104 & 0.039 \\
\hline 1.5 & 0.145 & 0.037 & 0.142 & 0.039 & 0.137 & 0.037 & 0.133 & 0.037 & 0.140 & 0.036 \\
\hline 1.8 & 0.185 & 0.040 & 0.179 & 0.037 & 0.174 & 0.037 & 0.169 & 0.036 & 0.176 & 0.036 \\
\hline 2.1 & 0.221 & 0.036 & 0.216 & & 0.216 & 0.042 & 0.206 & 0.037 & 0.213 & 0.037 \\
\hline 2.4 & 0.225 & & 0.254 & & & 0.032 & 0.243 & 0.037 & 0.251 & 0.038 \\
\hline 2.7 & 0.291 & 0.036 & 0.287 & 0.033 & $0.2 \overline{278}$ & 0.030 & & 0.037 & 0.285 & 0.034 \\
\hline 3. 0 & 0.321 & 0.030 & 0.325 & 0.038 & 0.316 & 0.038 & $0 . 3 \longdiv { 1 5 }$ & 0.035 & 0323 & 0.038 \\
\hline 3. 3 & 0.359 & 0.038 & 0.356 & & 0.351 & 0.035 & 0.349 & 0.034 & & 0.031 \\
\hline 36 & 0389 & 0.030 & 392 & 0.036 & & 0.032 & 200 & 0.034 & & 0.032 \\
\hline & & 0.032 & $\ldots$ & 0.033 & 0.000 & 0.032 & - & 0.031 & 0.380 & 0.037 \\
\hline 3.9 & 0.421 & 0,033 & 0.425 & 0.034 & 0.415 & & 0.414 & 0.035 & 0.423 & 0.030 \\
\hline 4. 2 & 0.454 & 0.000 & 0.459 & 0.0 & 0.451 & 0.030 & 0.449 & 0.035 & 0.453 & \\
\hline 4.5 & 0.486 & & 0.490 & 0.031 & 0.481 & 0.030 & 0.481 & & 0.484 & \\
\hline 4. 8 & 0.517 & 0.031 & 0.526 & 0.036 & 0.510 & 0.029 & 0.512 & 0.031 & 0.516 & 0.032 \\
\hline 5.1 & & 0.035 & & 0.029 & & 0.032 & & 0.033 & & 0.034 \\
\hline & & 0.031 & & 0.031 & & 0.032 & & 0.034 & & 0.031 \\
\hline 5.4 & 0.583 & & 0.586 & 0027 & 0.574 & 0034 & 0.579 & & 0.581 & \\
\hline 5.7 & 0.613 & & 0.613 & 0.021 & 0.608 & 0.054 & 0.608 & & 0.612 & .031 \\
\hline
\end{tabular}

\begin{tabular}{c|c|c|c|c|c|c}
\hline & 1st & 2nd & 3rd & 4th & 5 th & Average \\
\hline$l^{\mathrm{c})}(\mathrm{mm})$ & 598.714 & 598.743 & 598.745 & 598.741 & 598.743 & 598.737 \\
\hline
\end{tabular}

Note: a ) Lot-No. 414021 Cross sectional area of single fibre : $36.0\left(\mu \mathrm{m}^{2}\right)$

b ) Tensile modulus $\left(\mathrm{kgf} / \mathrm{mm}^{2}\right)=\frac{\text { load (constant) (gf) }}{\Delta \varepsilon(\%) \times \text { cross sectional area }\left(\mu \mathrm{m}^{2}\right) \times 10^{-6}}$

c) Gauge length : Distance between upper mark and lower mark at load $0.2 \mathrm{gf}$

に曲線上の 2 点を選び, 荷重の変化 $\Delta P$ に対応する 伸びの変化 $\Delta \varepsilon$ の比として式（3)によって 2 点閒の 弾性垶 $E$ を算出した。 Fig. 5 以外は, $\Delta P$ が $0.9 \mathrm{gf}$ になるように 2 点を選んだ. Fig. 5 は $\Delta P$ が $0.6 \mathrm{gf}$
になるようにした。このようにして荷重が $0.75 \mathrm{gf}$ から約 5 gf までの $E$ を求め, Fig. 2 から Fig.7の 左側に $E$ と $\varepsilon$ の関係としてプロットした， $E$ と $\varepsilon$ は, Fig.6 のようにばらつきの大きい例もあるが, 
modulus of elasticity of "Torayca" T300.a)

\begin{tabular}{|c|c|c|c|c|c|c|c|c|c|c|c|}
\hline \multirow{2}{*}{\multicolumn{2}{|c|}{$\begin{array}{c}3 \mathrm{rd} \\
\text { Decrease load }\end{array}$}} & \multicolumn{4}{|c|}{4 th } & \multirow{2}{*}{\multicolumn{2}{|c|}{$\begin{array}{l}\text { Elongation } \\
\varepsilon\end{array}$}} & \multirow{3}{*}{$\begin{array}{c}\text { Average } \\
\text { of } \\
\Delta \varepsilon \\
(\%)\end{array}$} & \multirow{2}{*}{\multicolumn{3}{|c|}{$\begin{array}{l}\text { Tensile modulus }{ }^{b)} \\
\left(10^{3} \mathrm{kgf} / \mathrm{mm}^{2}\right)\end{array}$}} \\
\hline & & \multicolumn{2}{|c|}{ Increase load } & \multicolumn{2}{|c|}{ Decrease load } & & & & & & \\
\hline $\begin{array}{c}\text { Elon- } \\
\text { gation } \\
\varepsilon \\
(\%)\end{array}$ & $\begin{array}{l}\Delta \varepsilon \\
(\%)\end{array}$ & $\begin{array}{c}\text { Elon- } \\
\text { gation } \\
\varepsilon \\
(\%)\end{array}$ & $\stackrel{\Delta \varepsilon}{(\%)}$ & $\begin{array}{c}\text { Elon- } \\
\text { gation } \\
\varepsilon \\
(\%)\end{array}$ & & $\begin{array}{c}\text { Average } \\
(\%)\end{array}$ & $\begin{array}{c}R \\
(\%)\end{array}$ & & $X$ & $\operatorname{Max}$ & Min \\
\hline 0.003 & \multirow[b]{2}{*}{0.027} & 0.003 & \multirow[b]{2}{*}{0.030} & 0.004 & \multirow[b]{2}{*}{0.026} & 0.003 & 0.003 & \multirow[b]{2}{*}{0.027} & \multirow[b]{2}{*}{30.9} & \multirow[b]{2}{*}{41.7} & \multirow[b]{2}{*}{27.8} \\
\hline 0.030 & & 0.033 & & & & & & & & & \\
\hline & 0.032 & & 0.036 & & 0.035 & & & 0.035 & 23.8 & 26.0 & 23.1 \\
\hline & \multirow{2}{*}{0.043} & & 0.033 & & 0.039 & & & 0.039 & 21.4 & 25.3 & 20.8 \\
\hline & & & \multirow{2}{*}{0.043} & & \multirow{2}{*}{0.036} & & & 0.038 & 21.9 & 23.1 & 19. 4 \\
\hline 0 & \multirow{2}{*}{0.038} & 0. & & & & & & 0.037 & 22.5 & 27.8 & 20.8 \\
\hline 0.180 & & 0.175 & & 0.178 & & 0.177 & 0.016 & & & & \\
\hline 0.212 & & 0.212 & & 0.214 & & 0.214 & 0.015 & r & & & \\
\hline 0.253 & 0.041 & 0.254 & 0.042 & 0.249 & 0.035 & 0.251 & 0.012 & 0.037 & 22.5 & 26.0 & 19.8 \\
\hline & 0.033 & & 0.029 & & 0.037 & & & 0.034 & 24.5 & 28.7 & 22.5 \\
\hline & 0.037 & & 0.036 & & 0.035 & & & 0.036 & 23. 1 & 27.8 & 21.9 \\
\hline 0.323 & & 0.319 & & 0.321 & & 0.320 & 0.010 & & & & \\
\hline 0.357 & & 0.351 & & 0.354 & & 0.354 & 0.010 & & & & \\
\hline 0.393 & & 0.387 & .036 & 0.388 & 0.034 & 0.388 & 0.010 & 0.034 & 24.5 & 27.8 & \\
\hline 0.423 & 0.030 & 0.419 & 0.032 & 0.4 & 0.029 & & & 0.032 & 26.0 & 28.7 & 22.5 \\
\hline 0. & 0.032 & 0.453 & 0.034 & 0.452 & 0.035 & & & 0.034 & 24.5 & 27.8 & 23. 1 \\
\hline & 0.033 & & 0.030 & & 0.033 & & & 0.032 & 26.0 & 27.8 & 25.3 \\
\hline 0 & & & & & 0.033 & & & 0.032 & 26.0 & 28.7 & 23.1 \\
\hline 0.520 & & 0.514 & & 0.518 & & 0.517 & 0.016 & & & & \\
\hline 0.554 & & 0.546 & & 0.550 & 0.0 & 0.549 & 0.013 & & & & \\
\hline 0.585 & 0.031 & 0.578 & 0.032 & 0.579 & 0.029 & 0.581 & 0.012 & 0.031 & 26.9 & 28.7 & 24.5 \\
\hline 0.612 & 0.027 & 0.609 & 0.031 & 0.609 & 0.030 & & & 0.030 & 27.8 & 30.9 & 24.5 \\
\hline
\end{tabular}

おおむ社值関係にある。すなわち，弾性率は伸び に比例し，次式で表わすことができる.

$$
E=E_{0}+E_{1} \varepsilon
$$

\section{ここで,}

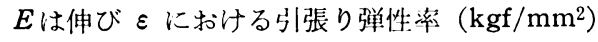

$E_{0}$ は伸び0における引張り弾性摔 $\left(\mathrm{kgf} / \mathrm{mm}^{2}\right)$

$E_{1}$ は $E-\varepsilon$ 関係の勾配 $\left(\mathrm{kgf} / \mathrm{mm}^{2}\right)$

$E_{0}$ および $E_{1}$ は珷料によって周有の俌をもつ.

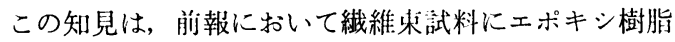
を含浸したのち加熟して硬化した細い棒状の複合材料 （樹脂含浸ヤーン陚料と呼称）について得た結果と一致
する. Curtis らの知見では, $0.1 \mathrm{gf}$ から $2.5 \mathrm{gf}$ までは 急激に弾性率が增大し, $2.5 \mathrm{gf}$ から $6 \mathrm{gf}$ の間は弾性率 は伸びに対して単調に增大するとしている. 本実験では, すべての陚料について，伸びの全域にわたり弾性率が 単調に增大することが想められ, Curtis らの結果とは一 致しない. Beetz らは, Curtis らと同様に音波伀播によ る弾性㳯の測定により，伸びのごく初期から単調增大寸 るとの絬果を報告しており，本実験と一致する．このこ とから Curtis らの知見との不一致は，音波伝播による 弾性摔の測定と本研究の機㑘的な方法による弾性率の測 定の差ではなく, Curtis らの場合には別の要因の存在を 

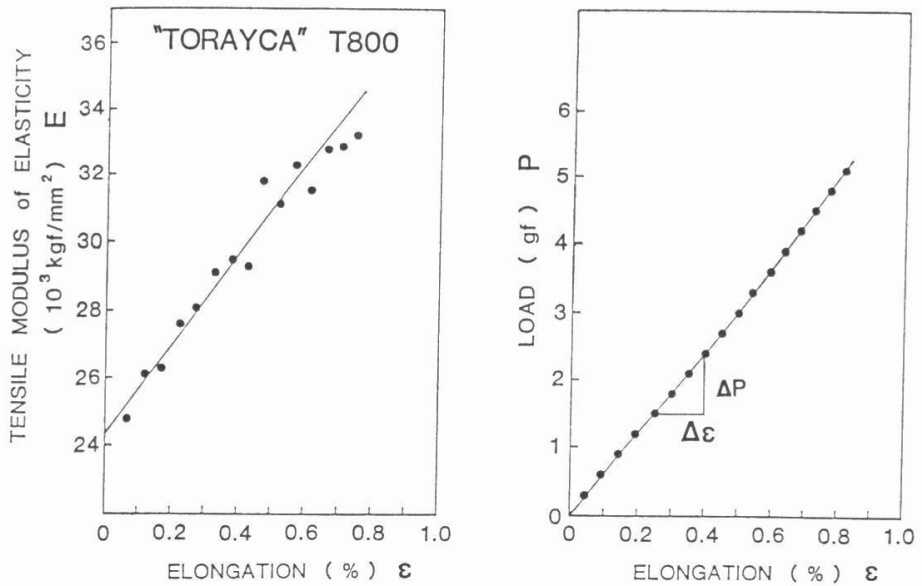

Fig. 4 Normal load vs. elongation, and tensile modulus vs. elongation for "Torayca" T800 fibre.
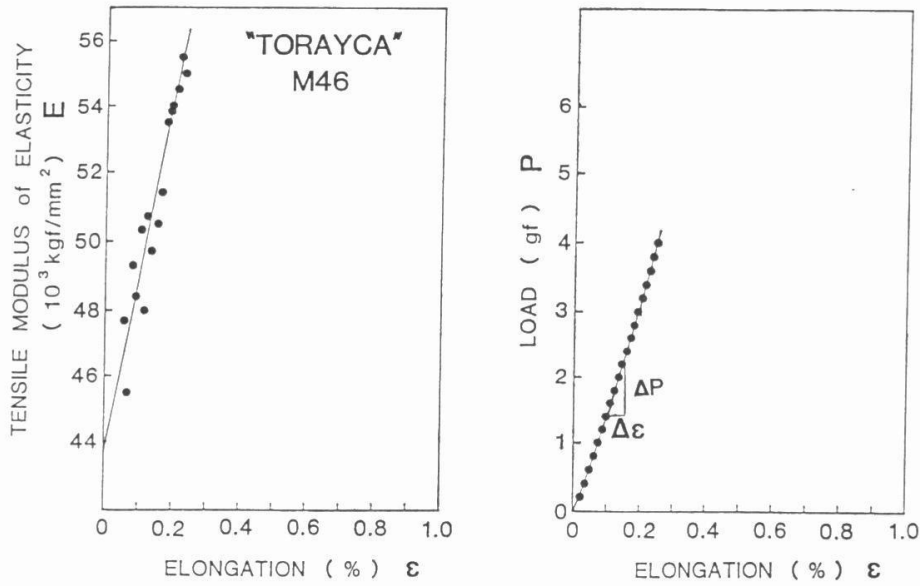

Fig. 5 Normal load vs. elongation, and tensile modulus vs. elongation for "Torayca" M46 fibre.

\section{考える必要がある。}

炭素繊維単繊維試料の引張り試験は, 試長 $25 \mathrm{~mm}$ 力 ら $50 \mathrm{~mm}$ で行ならことが多い、,10)。本研究では測定の 精度を向上するため, 試長を $900 \mathrm{~mm}$ にした。この試 長は, 通常に比べて著しく長い、繊維の試験を行ならに あたり材料は均質であり，断面積は試長内で一定である との前提にたっている，夷際には，材料の均質性および 断面積の一定性の非破壊試験がむずかしいので，この解 提の検証は行なわれていない，著しく長い、試長の試料に ついて得られた值の妥当性を調べ，この前提を間接的に 検証するため，試長を $900 \mathrm{~mm}$ の他に $650 \mathrm{~mm}, 450 \mathrm{~mm}$ および $330 \mathrm{~mm}$ に変えて引張り試験を行なった。 T300,
T800, AS4 およびIM6 について得られた結果を, Table 3 に示す．引張り弾性率は，荷重一伸び関係の荷重 $1.2 \mathrm{gf}$ と $3.0 \mathrm{gf} の 2$ 点間の勾配から計算した。試験片の数は 30 であり, 結果は平均值と変動率によって表わした。弾 性率は, 各試料とも, 試長に関係なく一定の值を示すこ とがわかった。弾性率の変動率は, 試長の短いときのほ うが大きい傾们にある。この結果から, 試長 $900 \mathrm{~mm}$ に ついて得た絬果は要当であることならびに試長 $300 \mathrm{~mm}$ から $900 \mathrm{~mm}$ の閒には顕著な不均質および断面積の不均 一がないと考えてよい, 変動率の試長依存性の原因は, わからない。

引張り弾性率の試長依存性の実験結果によると，個々 

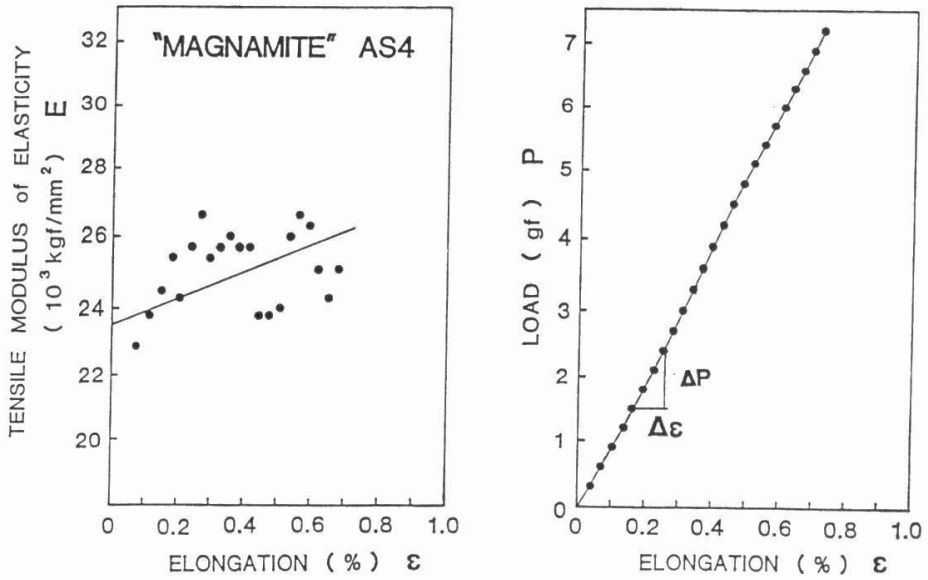

Fig. 6 Normal load vs. elongation, and tensile modulus vs. elongation for "Magnamite" AS4 fibre.
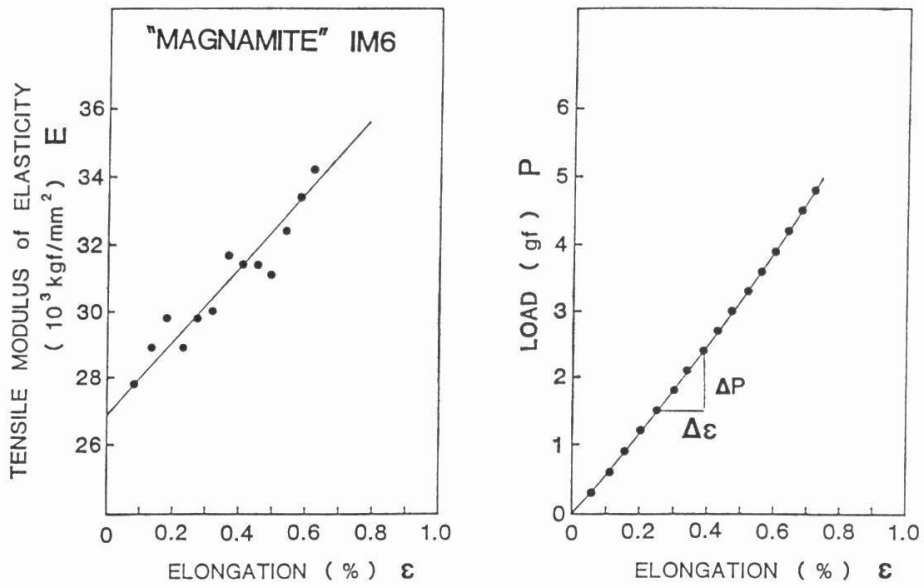

Fig. 7 Normal load vs. elongation, and tensile modulus vs. elongation for "Magnamite" IM6 fibre.

の值にばらつきがあり, 試長によって変わるが変動率 6 $\%$ から $17 \%$ に及ぶ. 弾性率のばらつきは, 式 (3)の $\Delta P, \Delta \varepsilon$ 㧊よび $A$ のばらつさに原因するが， $\Delta P$ は口一 ドセルの精度, $\Delta \varepsilon$ は測長器の精度に関係し，それぞれ 別途行なった精度検定により無視できることを確認して いる. $A$ は, 綫維束の単位長さ当り質量と密度から計算 によって求めた平均断面積であり, 各単繊維試験片ごと に測定した值ではなく，同一試料については一定值を用 いた，弾性率のばらつきは，断面積のばらつきによるか または断面積が一定で繊維の材質そのものにばらつきが あるためのいずれかである。

弾性率および断面積のばらつきの実態を調査するた
め, T300, T800, AS4 特よび IM6 について 120 点の 引張り試験結果を解析し, 走査電䫓写真のイメージアナ ライザー処理による断面積の湘定を行なった．引張り弾 性率は, 荷重 $1.2 \mathrm{gf}$ と $3.0 \mathrm{gf}$ 間 ( $\Delta P 1.8 \mathrm{gf})$ および $1.2 \mathrm{gf}$ と $4.8 \mathrm{gf}$ 間（ $\Delta P \quad 3.6 \mathrm{gf）の} 2$ 条件について計 算した. $\Delta P 3.6 \mathrm{gf}$ の場合には $4.8 \mathrm{gf}$ 以下で破断する 試験片があるため試験点数が 120 より小さいものがあ る. T300について得た結果を例示すると,

$\begin{array}{lrr}\Delta P(\mathrm{gf}) & 1.8 & 3.6 \\ \text { 平均值 }\left(\mathrm{kgf} / \mathrm{mm}^{2}\right) & 23900 & 24000 \\ \text { 最大值 }\left(\mathrm{kgf} / \mathrm{mm}^{2}\right) & 33600 & 31100 \\ \text { 最小值 }\left(\mathrm{kgf} / \mathrm{mm}^{2}\right) & 18900 & 18700\end{array}$


Table 3 Dependency of tensile modulus on the gauge length for four fibre samples.

\begin{tabular}{|c|c|c|c|c|c|c|c|c|}
\hline Fibre & \multicolumn{4}{|c|}{ T 300} & \multicolumn{4}{|c|}{ T 800} \\
\hline Gauge length (mm) & 330 & 450 & 650 & 900 & 330 & 450 & 650 & 900 \\
\hline Tesile modulus & 25.3 & 23.2 & 23.0 & 24.0 & 28.9 & 28.7 & 29.9 & 28.9 \\
\hline$\left(\times 10^{3} \mathrm{kgf} / \mathrm{mm}^{2}\right)$ & $(17.1)$ & $(10.3)$ & $(7.6)$ & $(6.2)$ & $(9.7)$ & $(10.5)$ & $(6.3)$ & $(6.4)$ \\
\hline Fibre & \multicolumn{4}{|c|}{ AS4 } & \multicolumn{4}{|c|}{ IM6 } \\
\hline Gauge length (mm) & 330 & 450 & 650 & 900 & 330 & 450 & 650 & 900 \\
\hline Tensile modulus & 24.2 & 23.9 & 22.8 & 24.2 & 28.7 & 27.3 & 28.2 & 28.4 \\
\hline$\left(\times 10^{3} \mathrm{kgf} / \mathrm{mm}^{2}\right)$ & $(15.3)$ & $(12.1)$ & $(10.6)$ & $(8.1)$ & & & $(7.3)$ & $(7.8)$ \\
\hline
\end{tabular}

Tensile modulus was represented as a chord modulus between $1.2 \mathrm{gf}$ and $3.0 \mathrm{gf}$ points and as a mean value.

Figure in parentheses was a coefficient of variation calculated for 30 observed values.

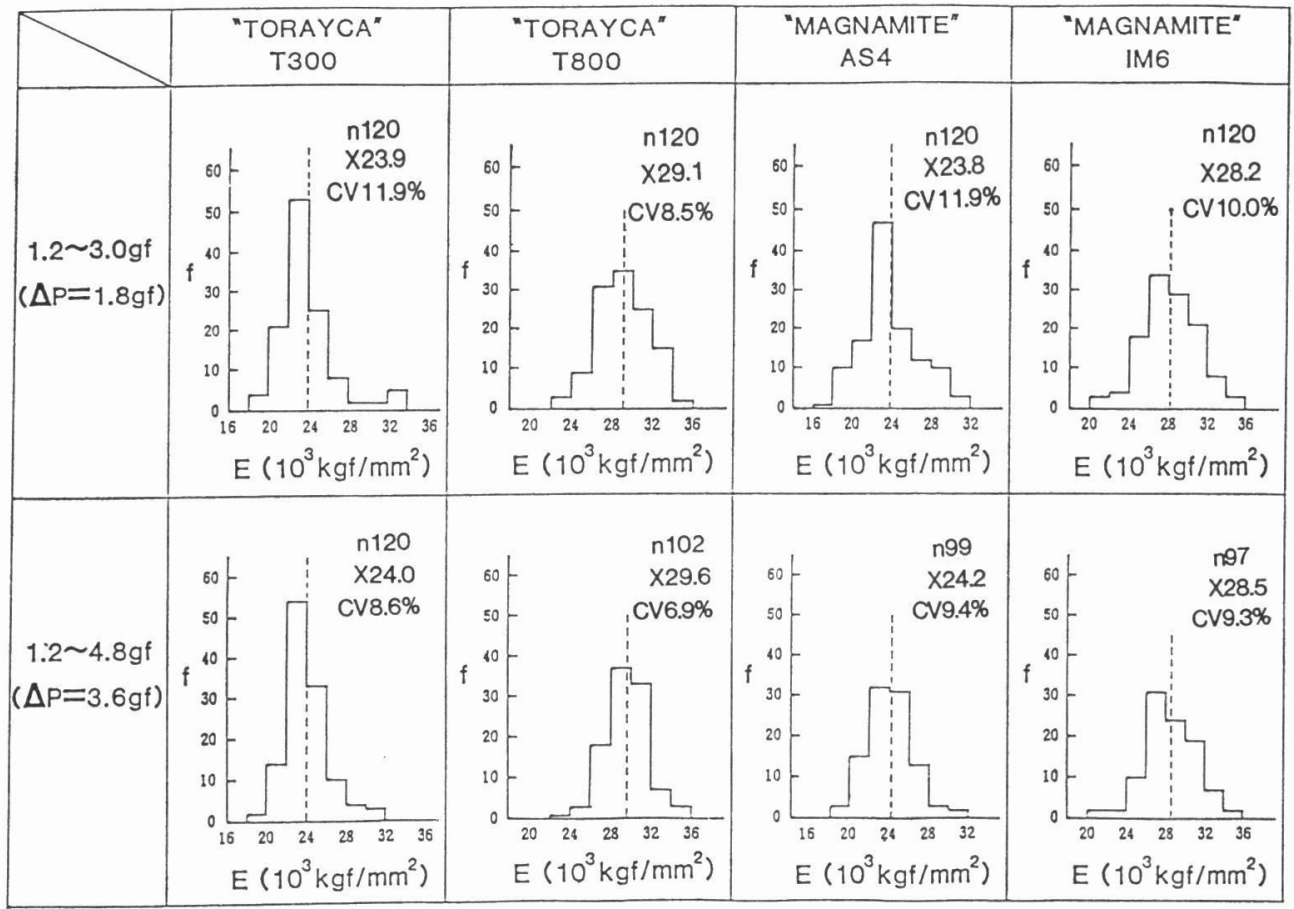

Fig. 8 Dispersion of tensile modulus for individual measurements, calculated as a chord modulus between $1.2 \mathrm{gf}$, and $3.0 \mathrm{gf}$, and $1.2 \mathrm{gf}$ and $4.8 \mathrm{gf}$.

$$
\text { 変動率 }(\%) \quad 11.9 \quad 8.5
$$

他の試料の結果もほぼ同様であり, 炭素絨維に共通して いる. Fig. 8 飞結果を示す. 分布は, ほぼ正規分布であ る.

単繊維試料の断面積は一定ではなく, 大小がある.
T300 について 54 点の測定結果を例示すると,

$\begin{array}{lr}\text { 平均值 }\left(\mu \mathrm{m}^{2}\right) & 38 \\ \text { 最大值 }\left(\mu \mathrm{m}^{2}\right) & 32 \\ \text { 最小値 }\left(\mu \mathrm{m}^{2}\right) & 42 \\ \text { 変動率 }(\%) & 6.7\end{array}$


A mean area, calculated by mass per unit length, density and filament counts of fibre bundle.

SEM photograph of cross section of fibre bundle was analyzed by an image analyzing instrument.

Fineness of a single filament specimen, which was determined by a selfexited oscillation method, and density of the fibre gave the cross sectional area of the specimen.

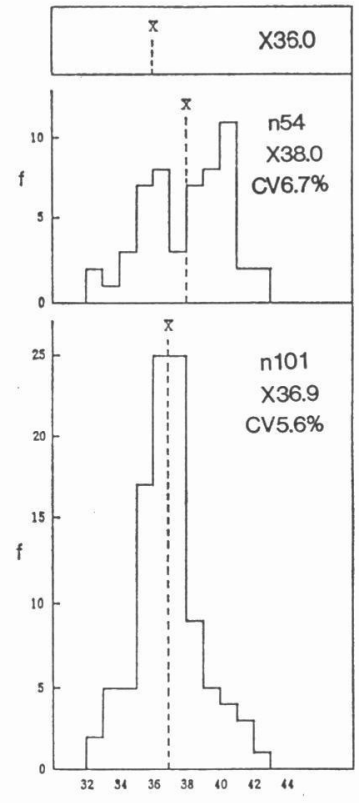

cross sectional area $\left(\mu \mathrm{m}^{2}\right)$

Fig. 9 Dispersion of cross sectional area of single filament for individual measurements for "Torayca" T300.

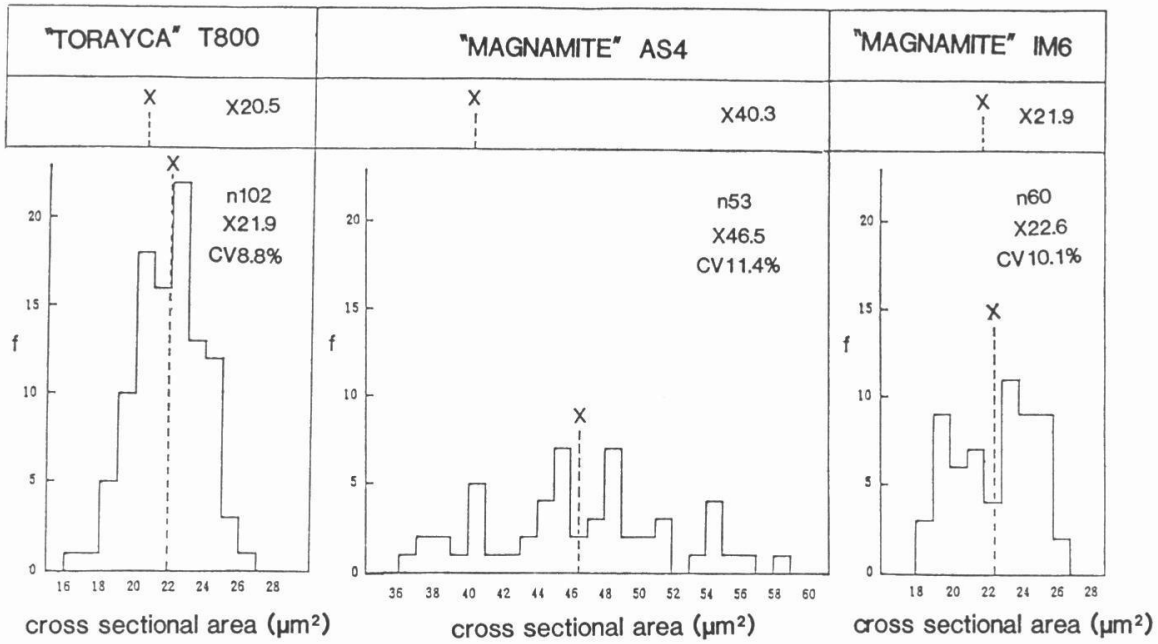

Fig. 10 Dispersion of cross sectional area for three samples, obtained by SEM photograph image analyzing instrument technique.

この結果の妥当性を確認するため自励振動による万法で 101 点の測定を行なった絬果, 平均值, 最大值, 最小值 扣よび変動率とも上掲の值とよく一致し，正しい結果が 得られたといえる. Fig. 9 に 3 種類の力法によって求め た T300 の断面積を示す. T800, AS4 および IM6 に
ついて走査電顕写真から測定した断面積は, T300 とほ 汴同様の結果であり，多少ばらつきの大小の点で差があ る. 結果を Fig. 10 に示与. 分布は, 正規分布である. 弾性率のばらつきが，断面積のばらつきによって現わ れたのか材質のぱらつきによるかに対し，これたけの央 
Table 4 Relation between dispersion of tensile modulus and dispersion of cross sectional area for four types of fibre samples.

\begin{tabular}{|c|c|c|c|}
\hline Sample & \multicolumn{2}{|c|}{$\begin{array}{c}\text { Coefficient of variation of tensile } \\
\text { modulus }(\%)\end{array}$} & $\begin{array}{c}\text { Coefficient of variation of cross } \\
\text { sectional area } \\
(\%)\end{array}$ \\
\hline “Torayca” Т300 & 11.9 & 8.6 & 6.7 \\
\hline "Torayca" T800 & 8.5 & 6.9 & 8.8 \\
\hline "Magnamite" AS4 & 11.9 & 9.4 & 11.4 \\
\hline "Magnamite" IM6 & 10.0 & 9.3 & 10.1 \\
\hline
\end{tabular}

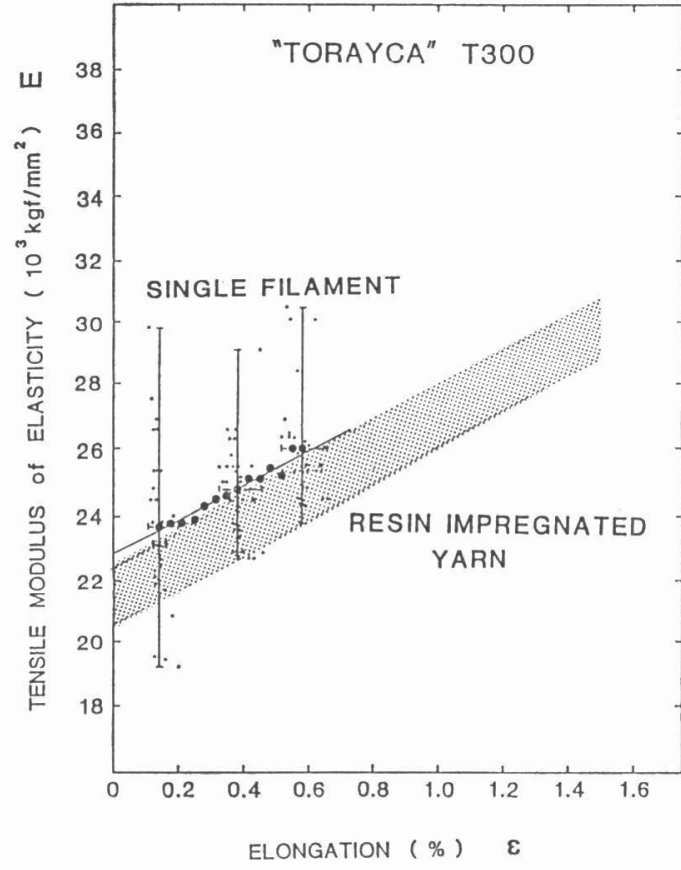

Fig.11 Average tensile modulus vs. elongation for "Torayca" T300 single filament sample. A shadowed line showes those for T300 resin impregnated yarn sample.

験で明解な結論をだすことはでさないが，4 種類の試料 について弾性率および断面積の分布から統計的に考える と両者間にきわめてよい相関があるので, 弾性率のばら つきは主として断面積のばらつきによるといってよい.

Table 4 に $\Delta P$ 1.8 gf 扎よび 3.6 gf の場合の弾性率の 変動率と断面積の变動率を比較して示す. T300 と T800 が逆転しているため, やや説得力に欠けるが，而特性の 变動率の大小に対応関係が認められる.

本研究の目的のひとつに，単繊維を多数本ひき揃えた 緎維束に樹脂を含浸して硬化した細い棒状複合材料を用

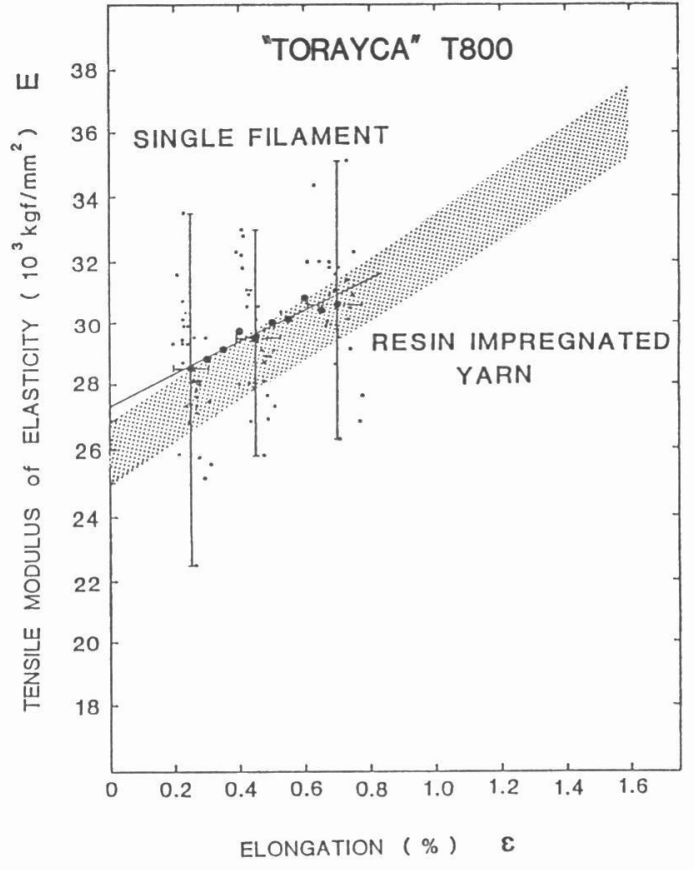

Fig.12 Average tensile modulus vs. elongation for "Torayca" T800 single filament sample. A shadowed line showes those for T800 resin impregnated yarn sample.

いて引張り弾性率を測定する場合, 単㵶維の配列の乱れ は不可避であり，この乱れが弾性率に及ぼす影響を明ら かにすることがある。先に述べたとおり単緎維の弾性率 のばらつきは, 主として断面積のばらつきによって起こ り材料の不均一性の影響は小さいと考えてよい，したが って試料の弾性率は平均断面積 $A$ を用いて計算した個々 の測定值の平均值で表現することができる。T300 およ び T800 について，単繊維試料 120 点の測定值の平均 值を伸びに対してプロットし，Fig. 11 および Fig. 12 に示す。個々の值は試験片の断面積の大小によるため, 
これを凮示する意味には乏しいが，参考のため無作為に 抽出した 30 点の值と範用をあわせて記入した。成中の ハッチングで示した帯は，樹脂含浸ヤーン陚料 30 点の 籁用を表わす。単繊維試料の弾性率は，樹脂含浸ヤーン 試料の弾性摔の上限に位置することおよび弾性率の伸び による変化は同一もしくはやや勾配が緩いことが明らか になった。この現象は，樹脂含浸ヤーン試料中で単緎維 が屈曲，俰角，施川して配列が乱れているために起こる と説明できる．試料に加わる応力の増大とともに弾性摔 が大きくなる伈力剛化（stress-stiffening）現象に対し て，単繊維の乱れが主要な原因であり，引張ると曲がっ ていた単繊維が伸びるために弾性摔が大きくなるという 考え方もある. しかし，ここで明らかにしたように，そ の影響は少なく, 応力剛化現象は炭素㵶維の本質である.

\section{4. 結論}

PAN 系炭素䋐維の単㵶維試料について精密な引張り 試験を行ない，荷重一伸びおよび伸びー弾性率の関係を調 植して次の結果を得た。

（1）炭素䋐維は弾性体であり，破媜荷重の約 $80 \%$ を 繰り返し負荷しても，除荷すると完全に回復する。

（2）荷重-伸びは非線性であり，荷重と伸びの勾配 $\Delta P / \Delta \varepsilon$ から求めた弾性率は伸びが大きくなる（荷重 が大きくなることと同義）とともに単調増大する.

この結果は, 前報で報告した樹脂含浸ヤーン試験につ いて得た結果と同じである.

（3）単緎維の断面積の測定がむずかしいので, 繊維束 (ヤーン) の単位長さ当り質量, 密度および単繊維 本数から部算した平均断面積 $A$ と $\Delta P / \Delta \varepsilon$ から弾性 率を求めたところ，引張り弾性率はかなりばらつき があり，変動率で表わして6〜17\% に達する。この 原内は，北として断面䅡のばらつきによる。

（4）単繊維試料および樹脂含浸ヤーン試料の引張り弾
性率を比較すると，単繊維がやや高めにある。また 弾性率の伸びによる変化は, 単繊維試料は樹脂含浸 ヤーン試料と同等もしくは勾配がやや小さい，この ことから樹脂含浸ヤーン陚料中では, 単繊維の屈曲, 施回，偏角などの配列の乱れがあり，引張り特性に その影響があらわれる。

単繊維試料は直径が $5 \mu \mathrm{m}$ とか $7 \mu \mathrm{m}$ であり，きわ めて紐く，きわめて弱く，その取扱いは非常にむずかし い.このような試料について試長 $900 \mathrm{~mm}$ の引張り試験 を行なった前例はなく，今回が最初であると思う。巧妙 な技術と根気によって夷験を担当した滋賀女子短期大学 水嶋明美さんに深甚なる謝意をあらわします。

\section{参考 文 献}

1) G.J. Curtis, J.M. Milne \& W.N. Reynolds : Nature, 220 (1968), 1024.

2) C.P. Beetz, Jr. \& G.W. Budd : Rev. Sci. Instrum., 54 (1983), 1222.

3）温品恭彦, 松井醇一, 伊藤 基 : 絨維学会誌, 42 (1986), T-182.

4) J.D. Hughes : J. Phys. D., 20 (1987), 276.

5) W.H. van Dreumel \& J.L. Kamp : J. Compos. Mater., 11 (1977), 461.

6) 石川隆司, 松嶋正道, 林 洋一：日本複合材料学 会誌, 12 (1986), 8.

7) JIS R7601-1986 炭素繊維試験方法.

8) A. Fourdeux, R. Perret \& W. Ruland : Carbon Fibres, Their Composites and Applications, The Plastic Inst., London (1971), p.57.

9) P.E. McMahon : Analysis of the Test Methods for High Modulus Fibers and Composites, ASTM STP 521 (1973), p. 367.

10) Standard test method for tensile strength and Young's modulus for high modulus single filament materials, ASTM D3379-75 (Reapproved 1982). 